\author{
Authors: \\ Chijioke Agomo (DProf); [The Institute for Work Based Learning, Middlesex University, London] \\ Arit Udoh (PhD); [Clinical Trial Unit, Anglia Ruskin University] \\ Eneyi Kpokiri [Doctoral Researcher - UCL School of Pharmacy, London] \\ John Osuku-Opio (PhD); [Locum community pharmacist, UK]
}

\title{
Community pharmacists' Contribution to public health: assessing the global evidence base
}

\begin{abstract}
In the UK, community pharmacies are more accessible to the general population than general practices. Therefore, government white papers and briefing documents from pharmacy professional bodies have advocated the expansion of the role of community pharmacists, particularly in relation to the provision of services that contribute to disease prevention and health improvement. It is unknown whether the same evidence exists globally for the expansion of these roles.
\end{abstract}

This article attempts to appraise and summarise the global evidence for the public health roles that community pharmacists play. Barriers, as well as strategies that can enhance these roles, are also discussed.

Electronic databases were searched to retrieve relevant literature published since 1 January 2000. The selected literature included 2 meta-analyses, 7 literature reviews, 23 interventional studies and 41 descriptive studies. These were assessed according to health topics (i.e. smoking cessation, weight management, health promotion, disease screening and preventive activities, vaccination and immunisation, alcohol dependence advice and drug misuse, emergency hormonal contraception, and sexual health services).

The effectiveness of community pharmacy-based public health interventions was shown in smoking cessation, health promotion, disease screening and preventive activities, provision of emergency hormonal contraceptive, and vaccination services. Although there was mixed evidence with respect to weight management and alcohol dependence advice interventions, the available data suggest feasibility and acceptability of these services due to the perceived ease of access and convenience.

Key points: 
- The effectiveness of community pharmacy-based public health interventions was shown in smoking cessation, health promotion, disease screening and preventive activities, provision of emergency hormonal contraceptive, and vaccination services.

- Overall, the evidence demonstrates that pharmacists are capable of providing both population-based and individual level public health services.

- However, strategies that can help facilitate and enhance community pharmacists' public health roles are needed.

- Further studies on cost-effectiveness of community pharmacists' public health intervention are also needed. 


\section{Introduction}

The World Health Organization (WHO) defines health as "A state of complete physical, mental and social wellbeing, and not merely the absence of infirmity" [1]. The main determinants of health include non-modifiable factors (e.g. age, sex and hereditary factors) and modifiable factors (e.g. individual lifestyle, social and community influences, living and working conditions, and general socio-economic, cultural and environmental conditions)[2]. Since these determinants were identified, there has been increased awareness of health as a global issue[3].

The UK Faculty of Public Health (FPH) defines public health as "The science and art of promoting and protecting health and wellbeing, preventing ill health and prolonging life through the organised efforts of society" [4]. Based on the FPH definition, public health is seen as population based; is focused on a collective responsibility for health, health protection and disease prevention; recognises the important role of the state, along with socio-economic and wider determinants of health; and stresses partnerships with all those whose actions contribute to the health of the population[4]. The FPH recognises three key domains of public health practice: health improvement, improving services and health protection. According to the WHO, activities that enhance public health capacities and services provide conditions that enable individuals to continue to be healthy, improve their wellbeing, or prevent the worsening of their health[5]. Therefore, public health focuses on the entire spectrum of health and wellbeing, not just the eradication of specific diseases[5]. While a number of activities are directed at specific populations (e.g. health campaigns), public health services also involve the provision of personal services, such as vaccinations, behavioural counselling and health advice [5].

Pharmaceutical public health is defined as "The application of pharmaceutical knowledge, skills and resources to the science and art of preventing disease, prolonging life, promoting, protecting and improving health for all, through organised efforts of society"[6]. British government white papers have advocated for the expansion of the role of the community pharmacist, particularly in relation to the provision of public health services [7], [8], [9], [10]. A key driver for this has been the increasing recognition of community pharmacists as one of the most accessible healthcare professionals with the ability to mitigate inequitable access to health services [11], [12], [13], [14]. One British government report indicates that $>90 \%$ of the general population will visit a community pharmacy at least once in a given year [12]. Reports also show that health services in community pharmacies are more accessible to the general population than general practices in the UK, with the majority of the population living within a 20-minute walk of a community pharmacy[15],[16]. Community pharmacists are also readily 
available and equipped with the knowledge and skills needed to meet the health-seeking behaviour of the society served, especially in relation to early disease prevention, health protection and health improvement[8],[12].

Even though pharmacy practice and education have evolved from an initial narrow, product-centred model to the present patient-centred model, it has done so to a varying degree in different countries [17]. While a number of meta-analyses and systematic literature reviews on the public health initiatives delivered by community pharmacists have been published in recent years[18],[19], these publications have primarily focused on the effectiveness of specific public health activities, such as smoking cessation[18],[19]; alcohol use, dependence and weight management[18]; and vaccination[20]. Some of these have focused on specific countries or regions [21]. This article aims to provide an overview of the global evidence (including UK studies) on the public health contributions of community pharmacists. Barriers, as well as strategies that can enhance these roles, will also be discussed.

\section{Methods}

The electronic databases SCOPUS, Web of Science, OvidSP, PubMed, MEDLINE and CINAHL were searched for relevant literature published since 1 January 2000. The keywords used were a combination of: community pharmacy, pharmacist, public health, health promotion, health improvement, health protection, disease prevention, and disease screening. A free text search using Boolean operators [OR \& AND] to combine words was conducted for the databases. Keyword truncation (i.e. pharm* and public*) was also utilised to ensure all relevant articles were included in the search. Keyword searches were also conducted on the Google Scholar platform. The reference lists of retrieved literature were further searched for relevant articles. A schematic of the literature selection process using Preferred Reporting Items for Systematic Reviews and Meta-Analysis (PRISMA) is presented in Figure 1. Studies included were those that reported: effectiveness, cost-effectiveness, and overall involvement of community pharmacists' public health activities. These included interventional, descriptive, and public health evaluation studies involving community pharmacists. Studies on public health initiatives or activities not based in a community pharmacy setting, editorials and research papers that did not include a clearly defined population, intervention or target group were excluded.

\section{Data Extraction}


Two of the review authors ( $A U$ and $C A$ ) independently screened all identified titles and their abstracts for relevance $(n=3,442)$. Full-paper manuscripts $(n=530)$ were then screened against the inclusion and exclusion criteria by AU, CA and EK, with the outcomes compared by JO-O to confirm consistency. The final list of selected papers was further assessed by JO-O to confirm the relevance of the identified studies with discrepancies resolved via consensus.

\section{Results}

In total, 73 articles were selected and included in this review. Evidence from systematic reviews and meta-analyses of community pharmacy-based public health interventions were reviewed according to published guidelines [22], [23], [24], [25]. Original articles already included in existing meta-analysis and systematic reviews selected for this paper were not further reviewed. The selected papers (see Table 1) were graded according to the quality of evidence grading system used in other published public health literature [21], [26], [27]:

- Level A: Evidence from meta-analyses or systematic reviews that included at least one randomised controlled trial (RCT);

- Level B: Evidence from individual RCTs or non-RCT, experimental or interventional studies, and individual non-experimental studies;

- Level C: Descriptive and other research or evaluation not in level B, including case studies and examples of good practice;

- Level D: Summary review articles and discussion of relevant literature and conference proceedings not otherwise classified;

- Level E: Expert opinion, case reports, focus groups or qualitative studies.

The selected literature included 2 meta-analyses, 7 literature reviews, 23 interventional and 41 descriptive studies (see Table 1). Evidence from the literature is presented according to health topics, including smoking cessation, weight management, health promotion, disease screening and preventive activities, vaccination and immunisation, alcohol dependence advice and drug misuse, emergency hormonal contraception and sexual health services. Other papers that reported perceptions and barriers to community pharmacists' involvement in public health activities, as well as strategies that can enhance their public health roles, are also presented under the respective themes. The reviews by Brown et al [18] and Anderson et al [27] covered multiple public health topics; their findings are reported according to the themes of this paper, as shown in Table 1. 
Literature identified through search of electronic databases $(n=29644)$

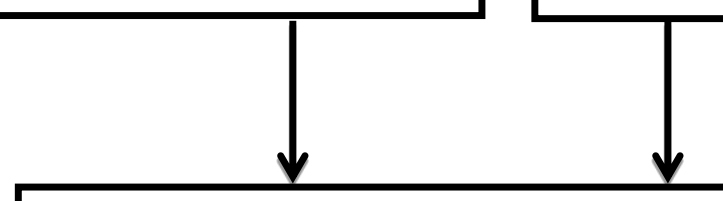

Records after duplicates removed $(n=14898)$
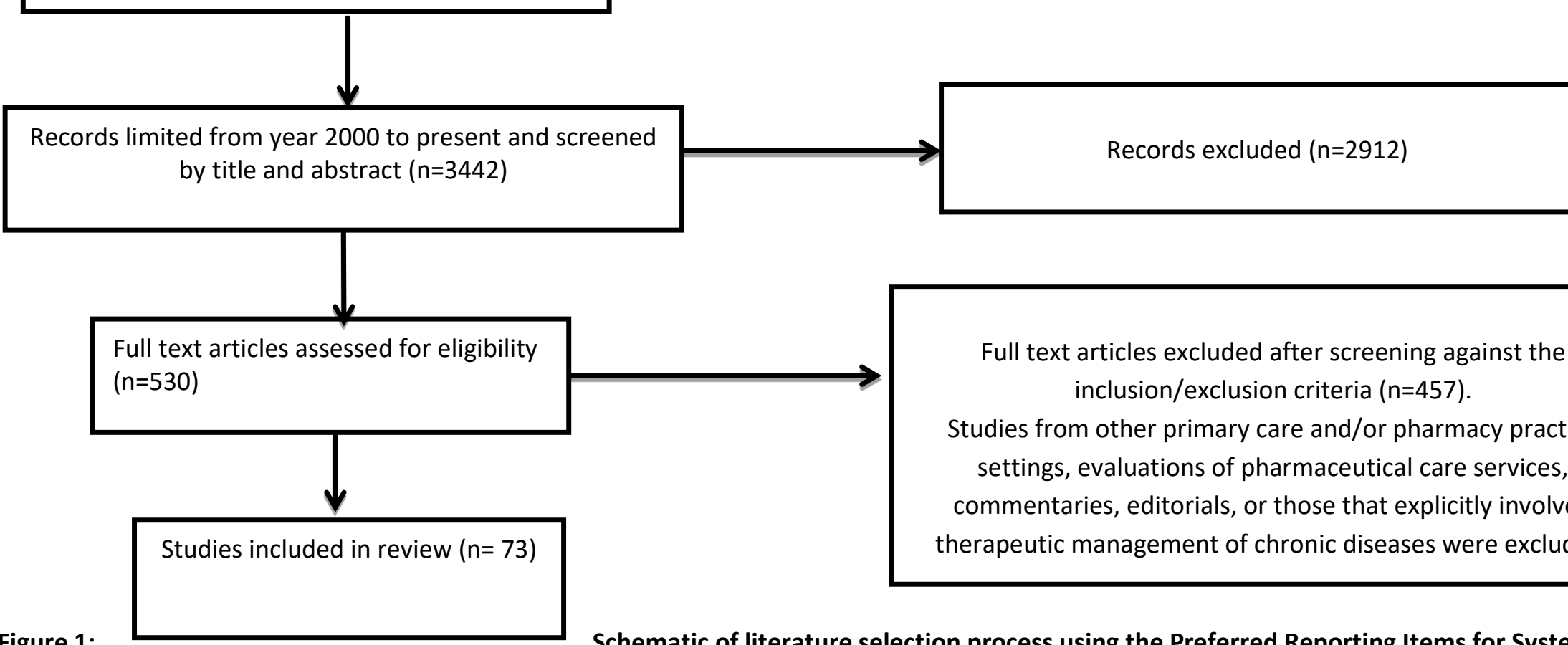

Figure 1:

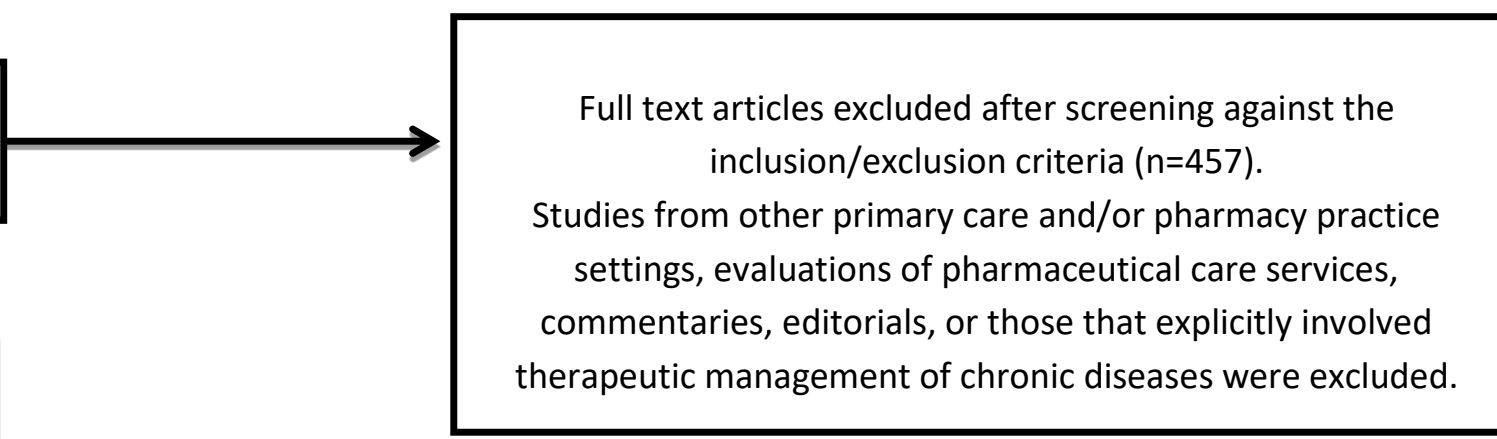

Reviews and Meta-Analysis (PRISMA)
Schematic of literature selection process using the Preferred Reporting Items for Systematic 
Table 1: Summary of Included papers

\begin{tabular}{|c|c|c|c|c|c|c|}
\hline $\begin{array}{l}\text { Public Health } \\
\text { Themes }\end{array}$ & $\begin{array}{l}\text { Publication/study } \\
\text { Type (N) }\end{array}$ & Author/year & Design & Country (N) & $\begin{array}{l}\text { Level of } \\
\text { Evidence }\end{array}$ & Summary \\
\hline \multirow[t]{5}{*}{$\begin{array}{l}\text { Smoking } \\
\text { cessation } \\
(\mathrm{N}=12)\end{array}$} & \multirow[t]{2}{*}{ Meta-analysis (2) } & Saba et al 2014 & $\begin{array}{l}\text { Included } 3 \text { RCT, } 2 \\
\text { before/after } \\
\text { studies with } \\
\text { control group }\end{array}$ & $\begin{array}{l}\text { Sweden (1), UK (3), USA } \\
(1) \text {, }\end{array}$ & \multirow[b]{2}{*}{ Level A } & \multirow{5}{*}{$\begin{array}{l}\text { Conclusive evidence on the } \\
\text { effectiveness of smoking cessation } \\
\text { services delivered by community } \\
\text { pharmacists. Cessation } \\
\text { interventions that included } \\
\text { provision of behavioural } \\
\text { modification counselling were } \\
\text { more effective. Time pressures } \\
\text { and non-availability of } \\
\text { appropriate training limited } \\
\text { implementation of service in } \\
\text { community pharmacies. }\end{array}$} \\
\hline & & *Brown et al 2016 & $\begin{array}{l}\text { Included 10RCT, } 1 \\
\text { nRCT, } 1 \\
\text { before/after study } \\
\text { with control group }\end{array}$ & $\begin{array}{l}\text { Australia (2), Japan (1), } \\
\text { Canada (1), UK (4), USA } \\
\text { (2), Netherlands (1) } \\
\text { Denmark (1) }\end{array}$ & & \\
\hline & \multirow[t]{2}{*}{$\begin{array}{l}\text { Literature review } \\
\text { (2) }\end{array}$} & *Anderson et al 2003 & $\begin{array}{l}\text { Included 2RCT, } 3 \\
\text { nRCT }\end{array}$ & $\begin{array}{l}\text { Sweden (1), Germany } \\
(1), \text { UK (2), Switzerland } \\
(1)\end{array}$ & Level A & \\
\hline & & Agomo 2012 & $\begin{array}{l}\text { Included } 4 \text { Surveys, } \\
1 \text { report, } 3 \\
\text { reviews, I guideline } \\
\text { document }\end{array}$ & $\begin{array}{l}\text { UK (4), USA (3), Malaysia } \\
\text { (1), Turkey (1) }\end{array}$ & Level A & \\
\hline & Descriptive (8) & $\begin{array}{l}\text { William et al 2000, } \\
\text { Çalgan 2007, } \\
\text { Thananithisak et al } \\
\text { 2008, Nimpitakpong } \\
\text { et al 2010, Hoch et al } \\
\text { 2012, Mohamed et al } \\
2013 \text {, Kurko et al } \\
2010, \text { El Hajj et al } \\
2012\end{array}$ & $\begin{array}{l}\text { Cross sectional } \\
\text { survey }\end{array}$ & $\begin{array}{l}\text { Qatar (1), UK (1), USA } \\
\text { (1), Finland (1) Thailand } \\
\text { (2), Turkey (1) and Sudan } \\
\text { (1) }\end{array}$ & Level C & \\
\hline
\end{tabular}




\begin{tabular}{|c|c|c|c|c|c|c|}
\hline $\begin{array}{l}\text { Public Health } \\
\text { Themes }\end{array}$ & $\begin{array}{l}\text { Publication/study } \\
\text { Type (N) }\end{array}$ & Author/year & Design (N) & Country (N) & $\begin{array}{l}\text { Level of } \\
\text { Evidence }\end{array}$ & Summary \\
\hline \multirow[t]{5}{*}{$\begin{array}{l}\text { Weight } \\
\text { Management } \\
(\mathrm{N}=7)\end{array}$} & $\begin{array}{l}\text { Literature review } \\
\text { (3) }\end{array}$ & $\begin{array}{l}\text { *Anderson et al } \\
2003\end{array}$ & $\begin{array}{l}\text { One before/after } \\
\text { study with no } \\
\text { control group }\end{array}$ & Denmark & Level B & \multirow{5}{*}{$\begin{array}{l}\text { Available evidence demonstrates the } \\
\text { feasibility and acceptability of the service, } \\
\text { however the data on effectiveness is mixed } \\
\text { relative to reduction in weight and BMI } \\
\text { compared to other primary care settings } \\
\text { and/or commercial providers. Interventions } \\
\text { that included lifestyle advice on diet, physical } \\
\text { activity and behavioural changes were more } \\
\text { effective. Privacy concerns, time constrains } \\
\text { and perceived lack of expertise and specialist } \\
\text { knowledge were key barriers identified from } \\
\text { consumer surveys. }\end{array}$} \\
\hline & & $\begin{array}{l}\text { *Brown et al } \\
2016 \text {, }\end{array}$ & $\begin{array}{l}\text { Included } 3 \mathrm{RCT}, 1 \\
\text { before/after study } \\
\text { with control group, } \\
1 \mathrm{nRCT}\end{array}$ & $\begin{array}{l}\text { UK (2), USA (2), } \\
\text { Thailand (1) }\end{array}$ & \multirow[t]{2}{*}{ Level A } & \\
\hline & & $\begin{array}{l}\text { Hermansyah et } \\
\text { al } 2016\end{array}$ & $1 \mathrm{RCT}$ & Thailand (1) & & \\
\hline & Intervention (1) & $\begin{array}{l}\text { Boardman and } \\
\text { Avery } 2014\end{array}$ & $\begin{array}{l}\text { Before and after } \\
\text { study with no } \\
\text { control group }\end{array}$ & UK (1) & Level B & \\
\hline & $\begin{array}{l}\text { Descriptive } \\
\text { (5) }\end{array}$ & $\begin{array}{l}\text { Newlands et al } \\
\text { 2011, } \\
\text { Weidmann et al } \\
\text { 2012, Um et al } \\
2012 \text {, Um et al } \\
2013 \text {, } \\
\text { Weidmann et al } \\
2015\end{array}$ & $\begin{array}{l}\text { Cross sectional } \\
\text { survey (3), } \\
\text { qualitative } \\
\text { interviews (2) }\end{array}$ & $\begin{array}{l}\text { UK (3), Australia } \\
(2)\end{array}$ & Level C & \\
\hline
\end{tabular}

*Reviewed multiple public health topics with the findings reported according to themes in this paper 


\begin{tabular}{|c|c|c|c|c|c|c|}
\hline $\begin{array}{l}\text { Public Health } \\
\text { Themes }\end{array}$ & $\begin{array}{l}\text { Publication/study } \\
\text { Type (N) }\end{array}$ & Author/year & Design & Country (N) & $\begin{array}{l}\text { Level of } \\
\text { Evidence }\end{array}$ & Summary \\
\hline \multirow{3}{*}{$\begin{array}{l}\text { Health } \\
\text { promotion and } \\
\text { education } \\
\text { campaigns } \\
(\mathrm{N}=8)\end{array}$} & Intervention (2) & Castillo-García et al 2011 & $\begin{array}{l}\text { Before/after } \\
\text { evaluation plus } \\
\text { cross sectional } \\
\text { survey }\end{array}$ & Spain & Level B & \multirow{3}{*}{$\begin{array}{l}\text { Effective in improving public } \\
\text { knowledge and awareness of } \\
\text { targeted health related issue. } \\
\text { Although pharmacists were } \\
\text { generally positive about role, they } \\
\text { indicated lack of knowledge and } \\
\text { inadequate training limited their } \\
\text { involvement in providing the service }\end{array}$} \\
\hline & & Murphy and Dipietro 2012 & $\begin{array}{l}\text { Before/after } \\
\text { with no control } \\
\text { group }\end{array}$ & USA & & \\
\hline & Descriptive (6) & $\begin{array}{l}\text { Laliberte et al 2012, } \\
\text { Schmiedel et al 2013, } \\
\text { Beshir and Bt Hamzah } \\
\text { 2014, Real et al 2014, } \\
\text { Ayoub et al } 2016, \\
\text { Mizoguchi et al } 2016\end{array}$ & $\begin{array}{l}\text { Cross sectional } \\
\text { survey and one } \\
\text { participatory } \\
\text { research }\end{array}$ & $\begin{array}{l}\text { Malaysia (1), } \\
\text { Jordan (1), Canada } \\
\text { (1), Argentina (1), } \\
\text { Germany (1), } \\
\text { Japan (1) }\end{array}$ & Level C & \\
\hline \multirow[t]{2}{*}{$\begin{array}{l}\text { Disease } \\
\text { Screening and } \\
\text { prevention } \\
\text { activities } \\
(\mathrm{N}=13)\end{array}$} & Intervention (9) & $\begin{array}{l}\text { Hourihan et al 2003, } \\
\text { Krass et al 2003, Krass et } \\
\text { al 2007, Peterson et al } \\
\text { 2010, Fuller et al 2011, } \\
\text { Perraudin et al 2015, } \\
\text { Sushilkumar 2015, Tsuyuki } \\
\text { et al 2016, Sandhu et al } \\
2016\end{array}$ & $\begin{array}{l}\text { 1RCT, Cohort } \\
\text { study with } \\
\text { follow up (8) }\end{array}$ & $\begin{array}{l}\text { Canada (2), } \\
\text { Australia (4), } \\
\text { France (1), New } \\
\text { Zealand (1) India } \\
(1)\end{array}$ & Level B & \multirow[t]{2}{*}{$\begin{array}{l}\text { Intervention increased access and } \\
\text { was effective in early identification } \\
\text { of at-risk group with subsequent } \\
\text { referral to physician. Also provides } \\
\text { an avenue for lifestyle modification } \\
\text { counselling to service users }\end{array}$} \\
\hline & Descriptive (4) & $\begin{array}{l}\text { Watson et al 2003, Weidle } \\
\text { et al 2014, Lowres et al } \\
2015 \text {, Schmiedel et al } \\
2016\end{array}$ & $\begin{array}{l}\text { Cross sectional } \\
\text { survey and one } \\
\text { qualitative } \\
\text { interview }\end{array}$ & $\begin{array}{l}\text { Australia (1), USA } \\
\text { (1), Germany (1), } \\
\text { UK (1) }\end{array}$ & Level C & \\
\hline
\end{tabular}




\begin{tabular}{|c|c|c|c|c|c|c|}
\hline $\begin{array}{l}\text { Public Health } \\
\text { Themes }\end{array}$ & $\begin{array}{l}\text { Publication/study } \\
\text { Type (N) }\end{array}$ & Author/year & Design & Country (N) & $\begin{array}{l}\text { Level of } \\
\text { Evidence }\end{array}$ & Summary \\
\hline \multirow[t]{3}{*}{$\begin{array}{l}\text { Vaccination and } \\
\text { immunization } \\
(\mathrm{N}=6)\end{array}$} & Literature review & $\begin{array}{l}\text { Burson et al } \\
2016)\end{array}$ & $\begin{array}{l}\text { Included } 25 \text { cross } \\
\text { sectional surveys, } 4 \\
\text { cohort studies, } 4 \text { case } \\
\text { control studies, } 4 \\
\text { experimental studies, } 3 \\
\text { modelling studies, } 7 \\
\text { single-subject design }\end{array}$ & USA (47) & Level A & \multirow[t]{3}{*}{$\begin{array}{l}\text { Data indicates that community } \\
\text { pharmacists' involvement in service } \\
\text { provision improved coverage, } \\
\text { expanded access and increased } \\
\text { likelihood of uptake }\end{array}$} \\
\hline & Intervention (2) & $\begin{array}{l}\text { Isenor et al 2016, } \\
\text { Buchan et al } 2017\end{array}$ & $\begin{array}{l}\text { Before/after with no } \\
\text { control group }\end{array}$ & Canada (2) & Level B & \\
\hline & Descriptive (3) & $\begin{array}{l}\text { Valiquette and } \\
\text { Bédard } 2015, \\
\text { Evans et al 2016, } \\
\text { Kulczycki et al } \\
2017\end{array}$ & $\begin{array}{l}\text { Qualitative interviews } \\
\text { and one cross sectional } \\
\text { survey }\end{array}$ & $\begin{array}{l}\text { UK (1), Canada } \\
(1), \text { USA (1) }\end{array}$ & Level C & \\
\hline \multirow{5}{*}{$\begin{array}{l}\text { Alcohol } \\
\text { dependence } \\
\text { advice and drug } \\
\text { misuse services } \\
(\mathrm{N}=6)\end{array}$} & \multirow[t]{2}{*}{$\begin{array}{l}\text { Literature review } \\
\text { (2) }\end{array}$} & $\begin{array}{l}\text { Watson and } \\
\text { Blenkinsopp } 2009\end{array}$ & $\begin{array}{l}3 \text { before/after studies } \\
\text { with no control group }\end{array}$ & UK (3) & Level B & \multirow{5}{*}{$\begin{array}{l}\text { Limited evidence on effectiveness of } \\
\text { service. The literature also reports } \\
\text { poor uptake by the public and } \\
\text { limited overall involvement by } \\
\text { community pharmacists. This was } \\
\text { primarily due to lack of training, } \\
\text { adequate knowledge and } \\
\text { confidence in providing the service. } \\
\text { However, the evidence suggests } \\
\text { feasibility and acceptability of the } \\
\text { service. }\end{array}$} \\
\hline & & *Brown et al 2016 & $2 \mathrm{RCT}$ & UK (2) & Level $A$ & \\
\hline & \multirow[t]{2}{*}{ Intervention (2) } & Khan et al 2013 & $\begin{array}{l}\text { Before/after study with } \\
\text { no control group }\end{array}$ & UK & \multirow[t]{2}{*}{ Level B } & \\
\hline & & $\begin{array}{l}\text { Cochran et al } \\
2016\end{array}$ & Cohort study & USA & & \\
\hline & Descriptive (3) & $\begin{array}{l}\text { McCaig et al } \\
\text { 2011, Horsfield et } \\
\text { al 2011, Sheridan } \\
\text { et al } 2012\end{array}$ & $\begin{array}{l}\text { Cross sectional survey } \\
\text { and one qualitative } \\
\text { interview }\end{array}$ & $\begin{array}{l}\text { USA (1), New } \\
\text { Zealand (2) }\end{array}$ & Level C & \\
\hline
\end{tabular}




\begin{tabular}{|c|c|c|c|c|c|c|}
\hline $\begin{array}{l}\text { Public Health } \\
\text { Themes }\end{array}$ & $\begin{array}{l}\text { Publication/study } \\
\text { Type (N) }\end{array}$ & Author/year & Design & Country (N) & $\begin{array}{l}\text { Level of } \\
\text { Evidence }\end{array}$ & Summary \\
\hline \multirow[t]{5}{*}{$\begin{array}{l}\text { Emergency } \\
\text { contraception } \\
\text { and sexual } \\
\text { health } \\
(\mathrm{N}=4)\end{array}$} & \multirow[t]{3}{*}{$\begin{array}{l}\text { Literature review } \\
\text { (3) }\end{array}$} & *Anderson et al 2003 & $\begin{array}{l}3 \text { before/after study } \\
\text { with no control group, } 2 \\
\text { cross sectional surveys, } \\
\text { one qualitative } \\
\text { interview }\end{array}$ & UK (4), USA (2) & Level B & \multirow{5}{*}{$\begin{array}{l}\text { Promoted improved access to } \\
\text { emergency contraception with } \\
\text { users indicating they valued the } \\
\text { ease and convenience of the } \\
\text { service. }\end{array}$} \\
\hline & & $\begin{array}{l}\text { Anderson and } \\
\text { Blenkinsopp } 2006\end{array}$ & $\begin{array}{l}\text { Included one RCT, } 5 \\
\text { before/after studies, } 9 \\
\text { qualitative } \\
\text { interviews/focus groups } \\
\text { and cross sectional } \\
\text { surveys }\end{array}$ & $\begin{array}{l}\text { Canada (3), Sweden } \\
\text { (2), South Africa (1), } \\
\text { Europe (1), France (1), } \\
\text { Norway (1), Portugal } \\
\text { (1) USA (6), UK (7) }\end{array}$ & Level A & \\
\hline & & Agomo, 2012 & $\begin{array}{l}\text { One RCT, } 2 \text { reviews, } \\
\text { cohort study and cross } \\
\text { sectional surveys }\end{array}$ & $\begin{array}{l}\text { USA (4), Belgium (1), } \\
\text { UK (2) }\end{array}$ & Level A & \\
\hline & \multirow[t]{2}{*}{ Descriptive (2) } & Baraister et al 2007 & $\begin{array}{l}\text { Service evaluation plus } \\
\text { qualitative interview }\end{array}$ & UK (1) & Level C & \\
\hline & & $\begin{array}{l}\text { Gale and Watson } \\
2011\end{array}$ & Cross sectional survey & UK (1) & Level C & \\
\hline \multirow[t]{2}{*}{$\begin{array}{l}\text { Cost } \\
\text { effectiveness } \\
\text { studies } \\
(\mathrm{N}=8)\end{array}$} & Descriptive (3) & $\begin{array}{l}\text { Pharmacy Research } \\
\text { UK 2014, Royal } \\
\text { Pharmaceutical } \\
\text { Society 2014, Oswald } \\
\text { \& Adcock } 2016\end{array}$ & $\begin{array}{l}\text { Commissioned reports } \\
\text { (3) }\end{array}$ & UK (3) & Level B & \multirow{2}{*}{$\begin{array}{l}\text { Community pharmacy-based public } \\
\text { health services such as smoking } \\
\text { cessation and disease screening are } \\
\text { cost effective. Intervention cost are } \\
\text { off-set by reduction in use of other } \\
\text { health services and increased } \\
\text { quality adjusted life gained (QALYs) }\end{array}$} \\
\hline & Intervention (5) & $\begin{array}{l}\text { Thavorn \& } \\
\text { Chaiyakunapruk } \\
\text { 2008, Perraudin et al } \\
\text { 2013, Lowres et al } \\
\text { 2014, Wright et al } \\
\text { 2015a \& 2015b }\end{array}$ & $\begin{array}{l}\text { Cohort studies and one } \\
\text { economic modelling } \\
\text { estimate }\end{array}$ & $\begin{array}{l}\text { UK (2), Thailand (1), } \\
\text { France (1), Australia } \\
(1)\end{array}$ & Level B & \\
\hline
\end{tabular}




\begin{tabular}{|c|c|c|c|c|c|c|}
\hline $\begin{array}{l}\text { Public Health } \\
\text { Themes }\end{array}$ & $\begin{array}{l}\text { Publication/study } \\
\text { Type (N) }\end{array}$ & Author/year & Design & Country (N) & $\begin{array}{l}\text { Level of } \\
\text { Evidence }\end{array}$ & Summary \\
\hline $\begin{array}{l}\text { Perceptions, public } \\
\text { views and barriers to } \\
\text { implementation of } \\
\text { public health } \\
\text { services } \\
(\mathrm{N}=5)\end{array}$ & Descriptive (5) & $\begin{array}{l}\text { Bush et al 2009, } \\
\text { Agomo 2012a, } \\
\text { Agomo and } \\
\text { Ogunleye 2014, } \\
\text { Agomo 2012c, } \\
\text { Saramunee 2014 }\end{array}$ & $\begin{array}{l}\text { Qualitative } \\
\text { interview, focus } \\
\text { group, } 3 \text { cross } \\
\text { sectional surveys }\end{array}$ & UK (5) & Level C & $\begin{array}{l}\text { Community pharmacists generally had } \\
\text { positive views about their involvement } \\
\text { in public health activities. Barriers to } \\
\text { participation in these services include } \\
\text { time constrains, lack of training and } \\
\text { inadequate knowledge and skills. }\end{array}$ \\
\hline $\begin{array}{l}\text { Strategies that can } \\
\text { enhance the public } \\
\text { health roles of } \\
\text { community } \\
\text { pharmacists } \\
(\mathrm{N}=4)\end{array}$ & Descriptive (4) & $\begin{array}{l}\text { Agomo and } \\
\text { Ogunleye 2014, } \\
\text { Agomo et al } \\
2016 a, \text { Agomo et } \\
\text { al 2016b, Agomo } \\
\text { et al 2016c }\end{array}$ & $\begin{array}{l}\text { Cross sectional } \\
\text { survey and } \\
\text { qualitative } \\
\text { interview }\end{array}$ & UK (4) & Level C & $\begin{array}{l}\text { Strategies that can enhance public health } \\
\text { these roles of community pharmacists } \\
\text { including provision of appropriate } \\
\text { training, availability and familiarity with } \\
\text { guidelines, availability of regulatory } \\
\text { support and policies that encourage } \\
\text { participation in these activities. }\end{array}$ \\
\hline
\end{tabular}




\section{Smoking cessation services}

Two meta-analyses of community pharmacy-based smoking cessation interventions were included in this paper[18],[19]. The meta-analysis by Saba et al. with a total of 1,426 smokers demonstrated better abstinence rates in the intervention group compared with usual care (relative risk [RR]: 2.21; 95\% confidence interval [CI]: 1.49-3.29)[19]. The paper by Brown et al., including more than 11,000 smokers, showed higher odds to quit smoking with community pharmacists' interventions. The odds of quitting varied depending on whether the metaregression model used accounted for the use of an active comparator group (pooled odds ratio [OR]: $1.21 ; 95 \% \mathrm{Cl}: 0.86-1.71$ ) or a non-active and usual care comparator (pooled OR: $2.56 ; 95 \% \mathrm{Cl}: 1.45$ to 4.53 )[18]. The usual care and non-active comparators in the meta-analyses were primarily observation only, ad hoc smoking cessation advice, use of placebo nicotine patches and standard smoking cessation counselling. The findings are similar to the conclusions of two literature reviews that indicate community pharmacists' smoking cessation initiatives are effective in helping patients stop smoking[26],[27]. The review by Anderson et al. also showed that interventions incorporating counselling and behavioural change methods by community pharmacists were more effective[27] - a finding that was supported by a scoping review[26]. Evidence from six survey studies indicate that community pharmacists had positive perceptions of their roles in providing smoking cessation services, although self-reported involvement in these activities ranged from 21\% in Qatar[28], 39\% in the United States[29], 51-71\% in Thailand[30],[31], 73\% in Turkey[32] and 76\% in Sudan[33]. Two studies showed that training[34], and availability, access to and familiarity with smoking cessation guidelines[35] improved community pharmacists' knowledge and involvement in providing smoking cessation services.

\section{Weight management}

Three literature reviews showed mixed evidence on the effectiveness of community pharmacy-based weight-management interventions [18], [21], [27]. One of the reviews concluded that although there was a reduction in body mass index (BMI), waist circumference and weight loss with community pharmacy-based weight-management interventions, the service did not result in a statistically significant difference in these outcomes when compared with other settings. A before/after UK study involving the provision of one-to-one advice and a weight loss handbook $(n=281)$ in the intervention arm demonstrated a significant reduction in weight and waist circumference from baseline (mean change: $-3.07 \mathrm{~kg}$ and $-3.87 \mathrm{~cm}$, respectively) [36]. The review by Anderson et al. and an Australian study that involved semi-structured interviews with experts demonstrates that multi-component community pharmacy-based weight-management interventions that included advice on diet, physical activity and behavioural changes were likely to be more effective[27],[37]. The review by Hermansyah 
et al. demonstrates that while there was no improvement in BMI, waist circumference and weight for the intervention group that received counselling, routine monitoring and comprehensive treatment, their theory of planned behaviours sum score significantly increased from baseline, including the intention to implement healthy eating behaviour $(P<0.05)$ and overall knowledge $(6.42 \pm 1.94$ to $8.75 \pm 0.68 ; \mathrm{P}<0.05$ ) compared with the control group [21]. Overall, the weight-management services offered by community pharmacists included the supply of weight-loss medication and advice, provision of dietary and physical activity counselling, and BMI measurement [38]. Generally, community pharmacy staff were positive and confident about providing the service, although they reported that their involvement in weight-management activities were mostly opportunistic and customer driven [39]. A survey designed to gather the views of the general public indicated that community pharmacy-based weight-management services were perceived to be easier and more convenient to access than in GP practices, although up to a quarter of the respondents expressed reservations about speaking to community pharmacy staff about their weight-related concerns[40]. Similar findings were reported by a patient survey conducted in Australia; most of the respondents had never sought weight-management advice from their community pharmacist, and those who had done so in the past expressed their willingness to support and pay for the service[41]. However, respondents also viewed the service as being primarily profit driven and perceived community pharmacists as lacking in expertise and time [41].

\section{Health Promotion Services and Educational Campaigns}

Two studies that evaluated the effectiveness of community health education campaigns delivered by community pharmacists demonstrate improvement in public knowledge [42] and awareness of the self-care needed to prevent diseases [43]. An interventional study evaluating knowledge and perceptions after the implementation of a similar campaign also demonstrated an increase in patient satisfaction and knowledge on the health issue targeted [44]. Patients who participated in the campaign had better perceptions of the pharmacist and recognised the community pharmacy as a reference point for resolving health problems [44]. Studies from Malaysia [45], Jordan [46], Argentina [47] and Canada [48] showed that while community pharmacists generally had positive attitudes about their role in health promotion and education, actual involvement in these activities was limited. This was in contrast to a study that showed that up to $51 \%$ of community pharmacies in a province in Germany conduct a health campaign at least once per year [49]. Factors identified as barriers to community pharmacists' involvement in delivery of health promotion and education campaigns included lack of time, poor training, lack of physical space, and inadequate knowledge and skill specific to the target subject [45], [46], [47], [48]. 


\section{Health Screening and Disease Prevention Activities}

Several published studies demonstrate the effectiveness of community pharmacy-based disease screening in promoting early detection and identification of patients at risk of stroke[50], diabetes[51], diabetes and hypertension[52],[53], sleep disorders[54],[55], cardiovascular risk[56],[57],[58],[59] and HIV[60]. A screening programme involving 30 pharmacies and 1,145 participants in Canada showed that an integrated stroke screening programme identified a high prevalence of individuals who could benefit from stroke-prevention therapies [50]. High-risk participants in the study were offered lifestyle advice and counselling, and were referred for confirmatory testing with a physician. Three months' follow-up showed $17 \%$ of participants identified as at risk of atrial fibrillation (AF) started on treatment with an anticoagulant and $50 \%$ had improved blood pressure, while $71 \%$ had confirmatory diabetic testing. Similar findings were shown in a diabetes screening programme in Australia [51] and a combined diabetic and hypertension screening programme in Germany [52]. The Australian study showed that screening for diabetic risk factors combined with capillary blood glucose testing in community pharmacies improved the rate of diagnosis for the disease $(P=0.008)$ and resulted in fewer and higher uptake of referrals to GPs[51]. The findings were similar to that of the study conducted in Germany that was effective in identifying up to 190 participants with high blood pressure referring them for further assessment and treatment [52].

One RCT that included health screening, lifestyle advice and follow-up showed a $21 \%$ difference in change in risk for cardiovascular events $(\mathrm{P}<0.001)$ at three months, along with changes in low-density lipoprotein cholesterol, systolic blood pressure and glycosylated haemoglobin (HbA1c $0.2 \mathrm{mmol} / \mathrm{l}$, $9.37 \mathrm{mmHg}, 0.92 \%$, respectively $[\mathrm{P}<0.001])$ in the intervention group[57]. A similar study also demonstrated a statistically significant improvement in the knowledge of cardiovascular disease risk factors at follow-up, with almost half of the identified high-risk subjects reporting lifestyle changes or being started on a medication following referral to their GP [56].

Other studies also suggest that a community pharmacy-based intervention involving health promotion and screening for cardiovascular risk factors increased access and was effective in early identification of at-risk patients when combined with follow-up confirmatory testing[58],[59]. A pilot project in the United States that tested the feasibility of offering a rapid, point-of-care HIV testing service showed that availability of the service in community pharmacies and retail clinics was a feasible model [60]. In addition, the study confirmed that staff at community pharmacies and retail clinics were willing and able to provide confidential HIV testing to clients [60]. An Australian study that developed, implemented and evaluated a community pharmacist-led sleep health and screening programme 
$(n=325)$ identified $44 \%$ of the target population to be at risk of one or more sleep disorders [54]. Further diagnosis from the referrals provided showed that community pharmacists could raise awareness and assist in initiating behavioural changes in those at risk of developing a sleep disorder [54]. A related study showed that the intervention was associated with higher odds of undergoing a diagnostic test for sleep disorders (adjusted OR: 2.24; 95\% Cl: 1.25-4.01) [61]. A qualitative study of participants' views of an AF screening service using an electrocardiogram (ECG) app in community pharmacies in Australia suggests that the service is acceptable, easy to use and feasible. However, the authors mentioned that the service would only be sustainable if adequately remunerated and combined with other cardiovascular screening services [62]. A UK study assessing current practice, knowledge and attitudes demonstrated that there is untapped potential for community pharmacists to become a focus for advice and information relating to prevention of HIV and hepatitis B and C [63].

\section{Vaccination and Immunization}

A retrospective study demonstrates an increase in vaccination coverage rate from $35.8 \%$ to $41.8 \%$ ( $P$ $<0.001)$ for those aged 5 years and under, and 9.8\% ( $P<0.001)$ for individuals aged 65 years and older in the province of Nova Scotia, Canada, one year after a policy change that allowed community pharmacists to administer influenza vaccine[64]. Similar findings were reported by another study that showed a $2.2 \%$ increase in influenza vaccine coverage and in individual likelihood of uptake (adjusted prevalence ratio: $1.05 ; 95 \% \mathrm{Cl} 1.02-1.08$ ) [65]. A literature review of 47 studies from the United States suggested that increased uptake and coverage for adult vaccination at community pharmacies was facilitated by regulatory changes and training programmes that allowed community pharmacists to administer vaccines [20]. The review also showed that vaccination services at community pharmacies were generally acceptable to patients, and could improve vaccination rates and increase coverage. The findings of surveys from the United States [66], UK [67] and Canada [68] indicate that community pharmacists were positive about providing vaccination services, but reported adequate training, remuneration and a collaborative relationship with general practitioners as factors that would improve implementation and uptake of the service.

\section{Alcohol Dependence Advice and Drug Misuse Services}

A review of two RCTs showed limited evidence on the effectiveness of community pharmacy-based alcohol dependence advice and counselling services [18]. The two studies involved provision of a brief alcohol advice service in a community pharmacy, compared with usual care. One of the studies $(n=407)$ showed no difference in the alcohol use disorder identification test (AUDIT) score $(-0.57 ; 95 \% \mathrm{CI}$ : 1.59 to -0.40$)$ between the intervention and control group, while the other $(n=69)$ showed no 
statistically significant difference in the fast alcohol screening tool (FAST) score $(-1.84 ; 95 \% \mathrm{Cl}:-4.49$ to -0.82 ) [18]. Similar findings were reported by another review of three studies showing that while there was a reduction in alcohol consumption in the intervention arm, it was not statistically significant [69].

Another intervention study showed poor uptake of the service with $21 \%$ of eligible participants agreeing to the service [70], although the study findings also demonstrated a significant reduction in seven-day alcohol unit consumption but no reduction in AUDIT scores [70]. A cross-sectional survey showed that while community pharmacists generally had positive views about their roles as providers of alcohol dependence advice services[71],[72], direct practice involvement was limited, with one study reporting just $5 \%$ of the respondents provided the service[39],[40].

Lack of knowledge and confidence in providing the service were identified as barriers[71], a finding that is similar to that from another survey involving community pharmacists in New Zealand and England[73]. A study from the United States, that recruited and screened a convenience sample of patients with the use of a tablet computer-based assessment protocol, showed a high prevalence of drug misuse in the study population and considered the feasibility of implementing regular opioid misuse screening protocols within community pharmacies[74]. Taken together, these studies indicate the viability of providing alcohol dependence advice and drug misuse services in community pharmacies, although further studies on effectiveness are needed.

\section{Emergency Hormonal Contraception and Sexual Health}

Three reviews demonstrated increased access to emergency hormonal contraceptives through community pharmacists' involvement in service provision, with a survey of user perception showing that the service was rated highly[26],[27],[75]. The review by Anderson et al. also reported an association between an observed reduction in attendance at the accident and emergency unit for emergency hormonal contraceptives services and availability in community pharmacies [75]. An evaluation of a Chlamydia testing service showed that service users valued the speed and convenience of accessing this through the community pharmacy, with $16 \%$ of the participants indicating they would not have taken up the service otherwise [76]. The review by Anderson et al. also showed that window displays were effective for raising client awareness of the availability of the service [27]. One survey that explored community pharmacists' views and perceptions as providers of sexual health services reported that the respondents were generally positive, but suggested that a lack of appropriate training, and inadequate knowledge and skills, limited implementation[77]. 


\section{Cost effectiveness of public health role of community pharmacists.}

A report by the UK Pharmaceutical Services Negotiating Committee indicates 12 services carried out by community pharmacies that delivered $£ 3.0 \mathrm{bn}$ in savings in 2015 , offsetting the $£ 2.8 \mathrm{bn}$ of total funding from the Department of Health [78]. Self-care support contributed the largest share of overall value at $40 \%$, followed by $31 \%$ for medicines support and $29 \%$ for public health [78]. Cost savings from community pharmacists' public health activities are also supported by the findings of other reports [79], [80], which show that the cost of treating common ailments, such as head lice, threadworms and athlete's foot, in community pharmacies was significantly lower at around $£ 29.30$ per patient, compared with $f 147.09$ per patient to treat the same ailments at accident and emergency units and $£ 82.34$ per patient at GP surgeries [79].

A UK study that screened patients at risk of chronic obstructive pulmonary disease (COPD) with validated tools reported that smoking cessation initiatives provided by community pharmacists gave a projected life gain of 38.62 years, 19.92 quality-adjusted life years (QALY) and a cost saving of $£ 392.67$ per patient screened [81]. A related study that evaluated the effect of a community pharmacy-based COPD service on patient outcomes reported significant improvements in patient adherence, utilisation of rescue packs, quality of life and a reduction in the number of routine GP visits [82], with the intervention cost offset by reductions in the use of other NHS services (GP, accident and emergency visits, and hospital admissions) [82]. Similar findings were reported by a smoking cessation service that showed overall cost savings to the healthcare system and life gains of 0.18 years for men and 0.24 years for women in Thailand [83]. This was also in line with a modelling estimate from a simulated sleep disorder screening service provided by community pharmacists that showed an estimated maximal incremental cost of $€ 455$ (£398.56) per QALY gained [84]. Another study that aimed to extend AF screening via a community pharmacy-based intervention using an iPhone ECG showed an incremental cost-effectiveness ratio of $A \cup \$ 5,988(£ 2,753.17)$ per QALY and AU\$30,481 $(£ 14,013.85)$ for preventing one stroke. Sensitivity analysis indicates that cost-effectiveness of the intervention improved with increased treatment adherence [85].

\section{Barriers to the public health role of community pharmacists}

A number of barriers to community pharmacists' involvement in public health activities have been identified [86]. These include the community pharmacy environment, which sometimes may not be suitable for the delivery of public health services - particularly with respect to privacy and confidentiality - as well as the perceptions of both the general public and other health providers of pharmacists' competencies[26], [87], [88], [89]. These barriers have also been reported in relation to 
provision of weight management [39], [40]; prevention of HIV, and hepatitis B and C [63]; and smoking cessation services [31]. Time pressure and high dispensing workload were also identified by studies on smoking cessation [31], flu vaccination uptake [67] and alcohol advice services [72]. Regulatory policies, inadequate training and lack of reimbursement for services were identified as barriers to public health service provision in community pharmacy by three UK studies [87], [88],[89]. Inadequate knowledge and skills specific to the target subject were also reported as limiting community pharmacists' involvement in delivery of health promotion and education campaigns[45], [46], [47], [48], weight management[38], sexual health[77] and alcohol dependence advice services[71]. Other challenges faced by community pharmacists included the structure and layout of community pharmacies[90], a lack of a well-defined career structure and progression channels, unacceptable work-life balance (leading to high stress levels)[91], the unavailability of individually contracted community pharmacists[92], and the declining ownership of community pharmacies by independent pharmacists [88], [93].

\section{Strategies that can enhance the public health role of community pharmacists}

The main themes identified in a UK study that could enhance the role of community pharmacists were: enhancing the public health content of the pharmacy training curricula; promoting interdisciplinary initiatives in pharmacy education and practice; promoting patients' self-management capacities and pharmacists' involvement through policies; remunerating pharmacists directly for providing public health services; and advancing the pharmaceutical public health practice experience of students [87]. These findings were also confirmed in other UK studies[94],[95], with evidence from the literature on specific public health interventions included in this paper showing that training[34], availability, access to, and familiarity with guidelines [34], [35] improved community pharmacists' knowledge, thus facilitating their involvement in providing public health services.

\section{Discussion}

The literature demonstrates that community pharmacy-based public health interventions have benefitted five key areas: smoking cessation, health promotion, disease screening and preventive activities, provision of emergency hormonal contraceptives, and vaccination services. There was mixed evidence with respect to the effectiveness of weight-management and alcohol-dependence advice interventions; however, the available data do suggest feasibility and acceptability of these service owing to the perceived ease of access and convenience[39], [40], [71], [72], [73]. These global findings add to the argument for the expansion of the public health roles of community pharmacists, as suggested by existing government reports and briefing documents [7], [10], [12]. Heterogeneity in 
pharmacy-based interventions in areas such as in smoking suggests the need for a standardised approach to service provision [18], [19]. This would ensure consistency in the quality of services provided [96], [97], [98]. However, it is important to highlight from the included descriptive studies that while community pharmacists were generally positive about their public health roles, they acknowledged the need for appropriate training targeted to these services. This may entail both updating the public health content of undergraduate pharmacy curricula[99],[100] and providing continuing professional development designed specifically for these services[34]. Such training would also need to be standardised, particularly as reports have shown variations in skill level of graduates from different countries as a result of disparities in undergraduate pharmacy training programmes [101]. There is also a need for policies that recognise community pharmacists as providers of public health services, as well as regulatory guidelines that provide a framework for service provision. This is of particular importance in view of emerging evidence from the UK that demonstrates the positive impact of government policy and professional guidelines on provision of flu vaccination by community pharmacists [102]. Similar findings from Canada and the United States[20],[64],[65] further emphasise this point, and are also consistent with evidence indicating that provision of and familiarity with practice guidelines facilitates the implementation and effectiveness of public health activities[35].

While the pharmacy profession is transitioning towards patient-centred care, with pharmacists contributing to micro-level public health activities (such as disease screening and preventive activities), there is a need to extend this role to macro-level public health functions, such as involvement in health planning, policy development and evaluation [103]. This must be done while also tackling many of the identified barriers in the public health role of community pharmacists.

\section{Limitations}

Although the authors aimed to provide an overview of the global evidence, the included literature were mainly from high-income countries (e.g. the UK, Canada and the United States). As a result, the generalisability of these findings to middle- and low-income countries with severe workforce shortages is likely to be limited. There were also observed limitations in the studies included in this paper. Only two studies in the Saba et al. meta-analysis [19] and five in the review by Brown et al. validated self-reported smoking abstinence via biochemical measures [18]. 
Details on the sampling method used for recruiting participating community pharmacies were also lacking in most of the smoking cessation intervention studies. Where reported, pharmacists and pharmacy recruitment was mainly via self-selection or purposive sampling - a finding that limits generalisability, given the inherent bias. Observed variability in the design of pharmacy-based weightmanagement interventions in the included studies biases the overall findings and conclusions. For example, the duration of weight-management intervention in the studies in the Brown et al. review [18] varied between 15 to 52 weeks. The intervention also involved the use of weight-management medication in one study, in contrast to the others that compared a combination of diet, physical activity and lifestyle counselling in different settings, including community pharmacies [18]. Demographics of study participants also varied between settings in one study [18] - a feature that further confounds the overall findings reported. Only one study on the effectiveness of pharmacybased health promotion and educational campaigns included in this paper provided specific details on the implementation of the intervention [43]. Where provided, the intervention involved the use of a convenience sample, further limiting generalisability. In addition, the studies on pharmacists' contribution to vaccination and immunisation [20] were primarily observational, with just one RCT included. This suggests limitations in internal validity and challenges with inferring causality, especially given the outcome measure of self-reported vaccination status [20]. Similar limitations were also observed in the studies on emergency hormonal contraception [75]. The difficulties in recruitment into one of the studies that evaluated the effectiveness of pharmacy-based alcohol advice services indicate that the research [70] was not statistically powered to detect an effect. Consequently, further work in this area is needed to explore factors that could improve uptake of the service. In general, the non-random sampling approach used in the recruitment of participating community pharmacists and pharmacies, as well as the small sample size in most of the descriptive studies, is another source of bias and suggests that the views of the respective study participants may not be representative.

Furthermore, evidence from the included studies must be interpreted in relation to the healthcare context in the respective countries, and therefore may not be generalisable to other countries with different healthcare systems. Overall, the evidence demonstrates that pharmacists are capable of providing both population-based and individual level public health services. However, strategies that can help facilitate and enhance community pharmacists' public health roles are needed.

\section{Conclusion}

This article discusses global evidence of community pharmacists' contributions to public health in the areas of smoking cessation, weight management, health education and promotion, disease screening 
and prevention, vaccination and immunisation, alcohol and drug misuse, and sexual health. There is evidence of cost savings resulting from community pharmacists' providing some of these services, but additional studies are needed to confirm the cost-effectiveness of all services, as well as whether the models proposed can be translated between different healthcare systems. However, time pressure, excessive workload, inadequate training, a poor community pharmacy environment, and a lack of reimbursement, among other factors, have been identified as barriers in the delivery of these roles. There is a need to address these in order facilitate efficient and effective delivery of these services by community pharmacists. Enhancing the public health content of undergraduate pharmacy curricula, remunerating pharmacists adequately and designing appropriate continuing professional development programmes are strategies that can enhance public health services delivered by community pharmacists.

\section{REFERENCES}

[1] World Health Organization. Constitution of WHO: principles. 2014. Available at: http://www.who.int/about/mission/en (accessed April 2018)

[2] Dahlgren G \& Whitehead M. Policies and strategies to promote social equity in health. 1991. Available at: https://core.ac.uk/download/pdf/6472456.pdf (accessed April 2018)

[3] Hunter DJ, Marks L \& Smith K. The public health system in England: a scoping study. 2007. Available at: https://core.ac.uk/download/pdf/28964369.pdf (accessed April 2018)

[4] Faculty of Public Health. What is public health? 2006. Available at: http://www.fph.org.uk/what_is_public_health (accessed April 2018)

[5] World Health Organization Regional Office of Europe. Public Health Services. 2015. Available at: http://www.euro.who.int/en/health-topics/Health-systems/public-health-services/public-healthservices (accessed April 2018)

[6] Walker R. Pharmaceutical public health: the end of pharmaceutical care? Pharm J 2000;264:340341.

[7] Braddick L, Bryson S, Crawford F et al. Pharmacy for Health: the Way Forward for Pharmaceutical Public Health in Scotland. 2002. Available at: http://www.healthscotland.com/uploads/documents/1728-pharmacy.pdf (accessed April 2018) 
[8] Department of Health. Healthy Lives, Healthy People: Our Strategy for Public Health in England. 2010. Available at:

https://www.gov.uk/government/uploads/system/uploads/attachment_data/file/216096/dh_12742 4.pdf (accessed April 2018)

[9] Department of Health. Pharmacy in England: Building on Strengths - Delivering the Future 2008. Available at: http://www.official-documents.gov.uk/document/cm73/7341/7341.pd (accessed April 2018)

[10] Public Health England. Consolidating and developing the evidence base and research for community pharmacy's contribution to public health: a progress report from Task Group 3 of the Pharmacy and Public Health Forum. 2014. Available at:

https://www.gov.uk/government/uploads/system/uploads/attachment_data/file/271682/20140110 -Community_pharmacy_contribution_to_public_health.pdf (accessed April 2018)

[11] Pharmaceutical Services Negotiating Committee, National Pharmaceutical Association, Royal Pharmaceutical Society of Great Britain \& Pharmacy Health Link. Public Health: a Practical Guide for Community Pharmacists. 2004. Available at: http://docplayer.net/15771152-Public-health-apractical-guide-for-community-pharmacists.html (accessed April 2018)

[12] Department of Health. Choosing health through pharmacy: a programme for pharmaceutical public health 2005-2015. 2005. Available at:

http://webarchive.nationalarchives.gov.uk/20130107105354/http://www.dh.gov.uk/prod_consum_ dh/groups/dh_digitalassets/@dh/@en/documents/digitalasset/dh_4107496.pdf (accessed April 2018)

[13] National Center for Chronic Disease Prevention and Health Promotion. A Program Guide for Public Health: Partnering with the Pharmacist in the Prevention and Control of Chronic Diseases. 2012. Available at: https://www.cdc.gov/dhdsp/programs/spha/docs/pharmacist_guide.pdf (accessed April 2018)

[14] World Health Organization. The role of pharmacists in the healthcare system: preparing the future pharmacist. 1997. http://apps.who.int/medicinedocs/pdf/s2214e/s2214e.pdf (accessed April 2018)

[15] Todd A, Copeland A, Husband A et al. Access all areas? An area-level analysis of accessibility to general practice and community pharmacy services in England by urbanity and social deprivation. BMJ Open 2015;5:e007328. doi: 10.1136/bmjopen-2014-007328 
[16] Todd A, Copeland A, Husband A et al. The positive pharmacy care law: an area-level analysis of the relationship between community pharmacy distribution, urbanity and social deprivation in England. BMJ Open 2014;4:e005764. doi: 10.1136/bmjopen-2014-005764

[17] Addo-Atuah J. Making a case for a public health orientation in global pharmacy education and practice in the context of the Millennium Development Goals (MDGs). Curr Pharm Teach Learn 2014;6(5):723-729. 10.1016/j.cptl.2014.05.019

[18] Brown TJ, Todd A, O'Malley C et al. Community pharmacy-delivered interventions for public health priorities: a systematic review of interventions for alcohol reduction, smoking cessation and weight management, including meta-analysis for smoking cessation. BMJ Open 2016;6:e009828. doi: 10.1136/bmjopen-2015-009828

[19] Saba M, Diep J, Saini B et al. Meta-analysis of the effectiveness of smoking cessation interventions in community pharmacy. J Clin Pharm Ther 2014;39(3):240-247. doi: 10.1111/jcpt.12131

[20] Burson RC, Buttenheim AM, Armstrong A et al. Community pharmacies as sites of adult vaccination: a systematic review. Hum Vaccines Immunother 2016;12(12):3146-3159. doi: $10.1080 / 21645515.2016 .1215393$

[21] Hermansyah A, Sainsbury E \& Krass I. Community pharmacy and emerging public health initiatives in developing Southeast Asian countries: a systematic review. Health Soc Care Community 2016;24(5):e11-e22. doi: 10.1111/hsc.12289

[22] Becker L \& Oxman AD. Overviews of reviews. In: Higgins JP \& Green S, eds. Cochrane Handbook for Systematic Reviews of Interventions. Version 5.0.02. Oxford: The Cochrane Collaboration; 2009.

[23] Biondi-Zoccai G. Umbrella Reviews: Evidence Synthesis with Overviews of Reviews and MetaEpidemiologic Studies. Switzerland: Springer International Publishing; 2016.

[24] National Institute for Health and Care Excellence. Methods for the development of NICE public health guidance. Process and methods (PMG4). 2012. Available at: https://www.nice.org.uk/process/pmg4/chapter/introduction (accessed April 2018)

[25] Smith V, Devane D, Begley CM et al. Methodology in conducting a systematic review of systematic reviews of healthcare interventions. BMC Med Res Methodol 2011;11:15. doi: 10.1186/1471-2288$11-15$ 
[26] Agomo CO. The role of community pharmacists in public health: a scoping review of the literature. J Pharm Health Serv Res 2012;3(1):25-33. doi: 10.1111/j.1759-8893.2011.00074.x

[27] Anderson C, Blenkinsopp A \& Armstrong M. The contribution of community pharmacy to improving the public's health REPORT 1 Evidence from the peer-reviewed literature 1990-2001. 2003. Available at:

http://eprints.nottingham.ac.uk/1571/1/The_contribution_of_community_pharmacy_to_improving _the_public\%27s_health_evidence_base_report_1.pdf (accessed April 2018)

[28] El Hajj MS, Al Nakeeb RR \& Al-Qudah RA. Smoking cessation counseling in Qatar: community pharmacists' attitudes, role perceptions and practices. Int J Clin Pharm 2012;34(4):667-676. doi: 10.1007/s11096-012-9663-x

[29] William D, Newsom J \& Brock T. An evaluation of smoking cessation-related activities by pharmacists. J Am Pharm Assoc 2000;40(3):366-370. doi: 10.1016/S1086-5802(16)31084-1

[30] Nimpitakpong P, Chaiyakunapruk N \& Dhippayom T. A national survey of training and smoking cessation services provided in community pharmacies in Thailand. J Community Health 2010;35(5):554-559. doi: 10.1007/s10900-010-9242-9

[31] Thananithisak C, Nimpitakpong P \& Chaiyakunapruk N. Activities and perceptions of pharmacists providing tobacco control services in community pharmacy in Thailand. Nicotine Tob Res 2008;10(5):921-925. doi: 10.1080/14622200802027115

[32]Çalgan Z, Tahir E, Yeğenoğlu S et al. Community pharmacists' attitude, habits and actual activities regarding smoking and health promotion in the 1. Region of Ankara chamber of pharmacists. Turk J Pharm Sci 2007;4(3):125-138. Available at: http://cms.galenos.com.tr/Uploads/Article_12541/125139.pdf (accessed April 2018)

[33] Mohamed SS, Mahmoud AA \& Ali AA. Involvement of Sudanese community pharmacists in public health activities. Int J Clin Pharm 2013;35(3):393-400. doi: 10.1007/s11096-012-9745-9

[34] Hoch MA, Hudmon KS, Lee L et al. Pharmacists' perceptions of participation in a community pharmacy-based nicotine replacement therapy distribution program. J Community Health 2012;37(4):848-854. doi: 10.1007/s10900-011-9519-7 
[35] Kurko T, Linden K, Pietilä K et al. Community pharmacists' involvement in smoking cessation: familiarity and implementation of the national smoking cessation guideline in Finland. BMC Public Health 2010;10:444. doi: 10.1186/1471-2458-10-444

[36] Boardman HF \& Avery AJ. Effectiveness of a community pharmacy weight management programme. Int J Clin Pharm 2014;36(4):800-806. doi: 10.1007/s11096-014-9964-3

[37] Um IS, Armour C, Krass I et al. Weight management in community pharmacy: what do the experts think? Int J Clin Pharm 2013;35(3): 447-454. doi: 10.1007/s11096-013-9761-4

[38] Newlands RS, Watson MC \& Lee AJ. The provision of current and future healthy weight management (HWM) services from community pharmacies: a survey of community pharmacists' attitudes, practice and future possibilities. Int J Pharm Pract 2011;19(2):106-114. doi: 10.1111/j.20427174.2010.00080.x

[39] Weidmann AE, MacLure K, Marshall S et al. Promoting weight management services in community pharmacy: perspectives of the pharmacy team in Scotland. Int J Clin Pharm 2015;37(4):599-606. doi: 10.1007/s11096-015-0102-7

[40] Weidmann AE, Cunningham S, Gray G et al. Views of the Scottish general public on community pharmacy weight management services: international implications. Int J Clin Pharm 2012;34(2):389397. doi: 10.1007/s11096-012-9624-4

[41] Um IS, Armour C, Krass I et al. Consumer perspectives about weight management services in a community pharmacy setting in NSW, Australia. Health Expect 2014;17: 579-592. doi: 10.1111/j.13697625.2012.00788.x

[42] Murphy BL \& DiPietro NA. Impact of a pharmacist-directed educational program on the long-term knowledge and use of folic acid among college women: a 12-month follow-up study. Pharm Pract 2012;10(2):105-109. PMID: 24155825.

[43] Mizoguchi M, Kuwano S, Suzuki I et al. Usefulness of oral care-related information provision at drugstores to prevent pneumonia. Yakugaku Zasshi 2016;136(12):1657-1666. doi: 10.1248/yakushi.16-00056

[44] Castillo-García ML, Martínez-Raga J, López-Castellano AC et al. Health education in the community pharmacy: controlled study in the province of Castellon [Educación sanitaria en la farmacia 
comunitaria: estudio controlado en la provincia de Castellón.]. ARS Pharm 2011;52(4):5-11. Available at: http://revistaseug.ugr.es/index.php/ars/article/view/4756 (accessed April 2018)

[45] Beshir SA \& Bt Hamzah NH. Health promotion and health education: perception, barriers and standard of practices of community pharmacists. Int J Health Promot Educ 2014;52(4):174-180. doi: $10.1080 / 14635240.2014 .888809$

[46] Ayoub NM, Nuseir KQ, Othman AK et al. Knowledge, attitudes and barriers towards breast cancer health education among community pharmacists. J Pharm Health Serv Res 2016;7(3):189-198. doi: 10.1111/jphs. 12140

[47] Real JP, Gracia Vásquez SL, Formica ML et al. Challenges and opportunities related to health promotion in community pharmacies: obstacles and professional perspectives. Pharm Policy Law 2014;16(3-4):313-320. doi: 10.3233/PPL-140391

[48] Laliberté $\mathrm{M}-\mathrm{C}$, Perreault $\mathrm{S}$, Damestoy $\mathrm{N}$ et al. Ideal and actual involvement of community pharmacists in health promotion and prevention: a cross-sectional study in Quebec, Canada. BMC Public Health 2012;12(1). doi: 10.1186/1471-2458-12-192

[49] Schmiedel K, Schlager H \& Dörje F. Preventive counselling for public health in pharmacies in South Germany. Int J Clin Pharm 2013;35(1):138-144. doi: 10.1007/s11096-012-9722-3

[50] Sandhu RK, Dolovich L, Deif B et al. High prevalence of modifiable stroke risk factors identified in a pharmacy-based screening programme. Open Heart 2016;3(2). doi: 10.1136/openhrt-2016-000515

[51] Krass I, Mitchell B, Clarke P et al. Pharmacy diabetes care program: analysis of two screening methods for undiagnosed type 2 diabetes in Australian community pharmacy. Diabetes Res Clin Pract 2007;75:339-347. doi: 10.1016/j.diabres.2006.06.022

[52] Schmiedel K, Friedland K \& Schlager H. Evaluation of the Activities of Community Pharmacies during the annual campaign with focus on diabetes prevention [Evaluation der Aktivitäten öffentlicher Apotheken im Rahmen der Jahresschwerpunktkampagne „Diabetes bewegt uns!"]. Gesundheitswesen 2016;78(10):678-680. doi: 10.1055/s-0035-1564216

[53] Sushilkumar PL, Mahendrakumar BJ, Suman B et al. Implementation and evaluation of health screening services to diabetic and hypertensive patients in a selected community pharmacy at Belgaum city. Asian J Pharm Clin Res 2015;8(3):305-315. Available at: https://innovareacademics.in/journals/index.php/ajpcr/article/view/5758 (accessed April 2018) 
[54] Fuller JM, Wong KK, Krass I et al. Sleep disorders screening, sleep health awareness, and patient follow-up by community pharmacists in Australia. Patient Educ Couns 2011;83(3):325-335. doi: 10.1016/j.pec.2011.05.004

[55] Perraudin C, Fleury B \& Pelletier-Fleury N. Effectiveness of intervention led by a community pharmacist for improving recognition of sleep apnea in primary care - a cohort study. J Sleep Res 2015;24(2):167-173. doi: 10.1111/jsr.12230

[56] Peterson GM, Jackson SL, Hughes JD et al. Public perceptions of the role of Australian pharmacists in cardiovascular disease. J Clin Pharm Ther 2010;35(6):671-677. doi: 10.1111/j.13652710.2009.01139.x

[57] Tsuyuki RT, Al Hamarneh YN, Jones CA et al. The Effectiveness of pharmacist interventions on cardiovascular risk: the multicenter randomized controlled RxEACH trial. J Am Coll Cardiol 2016;67(24):2846-2854. doi: 0.1016/j.jacc.2016.03.528

[58] Hourihan F, Krass I \& Chen T. Rural community pharmacy: a feasible site for a health promotion and screening service for cardiovascular risk factors. Aust J Rural Health 2003;11(1):28-35. Available at: https://onlinelibrary.wiley.com/doi/abs/10.1046/j.1440-1584.2003.00468.x (accessed April 2018)

[59] Krass I, Hourihan F \& Chen T. Health promotion and screening for cardiovascular risk factors in NSW: a community pharmacy model. Health Promot J Aust 2003;14:101-107. doi: 10.1071/HE03101

[60] Weidle PJ, Lecher S, Botts LW et al. HIV testing in community pharmacies and retail clinics: a model to expand access to screening for HIV infection. J Am Pharm Assoc 2014;54(5):486-492. doi: 10.1331/JAPhA.2014.14045

[61] Perraudin C, Fleury B \& Pelletier-Fleury N. Effectiveness of intervention led by a community pharmacist for improving recognition of sleep apnea in primary care - A cohort study. J Sleep Res 2015;24(2):167-173. doi: 10.1111/jsr.12230

[62] Lowres N, Krass I, Neubeck L et al. Atrial fibrillation screening in pharmacies using an iPhone ECG: a qualitative review of implementation. Int J Clin Pharm 2015;37:1111-1120. doi: 10.1007/s11096015-0169-1 
[63] Watson L, Bond C \& Gault C. A survey of community pharmacists on prevention of HIV and hepatitis B and C: current practice and attitudes in Grampian. J Public Health Med 2003;25(1):13-18. doi: 10.1093/pubmed/fdg004

[64] Isenor JE, Killen JL, Billard BA et al. Impact of pharmacists as immunizers on influenza vaccination coverage in the community-setting in Nova Scotia, Canada: 2013-2015. J Pharm Policy Pract 2016;9(1):32. doi: 10.1186/s40545-016-0084-4

[65] Buchan SA, Rosella LC, Finkelstein M et al. Impact of pharmacist administration of influenza vaccines on uptake in Canada. CMAJ 2017;189(4):E146-E152. doi: 10.1503/cmaj.151027

[66] Kulczycki A, Wensel TM \& Hogue M. Practices, challenges, and opportunities to improving pneumococcal immunization in working-age, at-risk adults through community pharmacies. Infect Dis Clin Pract 2017;25(1):23-28. doi: 10.1097/IPC.0000000000000452

[67] Evans AM, Wood FC \& Carter B. National community pharmacy NHS influenza vaccination service in Wales: a primary care mixed methods study. Br J Gen Pract 2016;66(645):e248-e257. doi: 10.3399/bjgp16X684349

[68] Valiquette JR \& Bédard P. Community pharmacists' knowledge, beliefs and attitudes towards immunization in Quebec. Can J Public Health 2015;106(3):e89-e94. doi: 10.17269/CJPH.106.4880

[69] Watson MC \& Blenkinsopp A. The feasibility of providing community pharmacy-based services for alcohol misuse: a literature review. Int J Pharm Pract 2009;17(4):199-205. doi: 10.1211/ijpp.17.04.0002

[70] Khan NS, Norman IJ, Dhital R et al. Alcohol brief intervention in community pharmacies: a feasibility study of outcomes and customer experiences. Int J Clin Pharm 2013;35(6):1178-1187. doi: 10.1007/s11096-013-9845-1

[71] McCaig D, Fitzgerald N \& Stewart D. Provision of advice on alcohol use in community pharmacy: a cross-sectional survey of pharmacists' practice, knowledge, views and confidence. Int J Pharm Pract 2011;19(3):171-178. doi: 10.1111/j.2042-7174.2011.00111.x

[72] Sheridan J, Stewart J, Smart R et al. Risky drinking among community pharmacy customers in New Zealand and their attitudes towards pharmacist screening and brief interventions. Drug Alcohol Rev 2012;31(1):56-63. doi: 10.1111/j.1465-3362.2011.00293.x 
[73] Horsfield E, Sheridan J \& Anderson C. What do community pharmacists think about undertaking screening and brief interventions with problem drinkers? Results of a qualitative study in New Zealand and England. Int J Pharm Pract 2011;19(3):192-200. doi: 10.1111/j.2042-7174.2011.00112.x

[74] Cochran G, Bacci JL, Ylioja T et al. Prescription opioid use: patient characteristics and misuse in community pharmacy. J Am Pharm Assoc 2016;56(3):248-256.e6. doi: 10.1016/j.japh.2016.02.012

[75] Anderson C \& Blenkinsopp A. Community pharmacy supply of emergency hormonal contraception: a structured literature review of international evidence. Hum Reprod Oxf Engl 2006;21(1):272-284. doi: 10.1093/humrep/dei287

[76] Baraitser P, Pearce V, Holmes J et al. Chlamydia testing in community pharmacies: evaluation of a feasibility pilot in south east London. Qual Saf Health Care 2007;16(4):303-307. doi: $10.1136 /$ qshc. 2006.020883

[77] Gale A \& Watson MC. The provision of current and future sexual health services from community pharmacies in Grampian, Scotland. Int J Clin Pharm 2011;33(2):183-190. doi: 10.1007/s11096-0109458-x

[78] Oswald K \& Adcock H. Community pharmacy care delivered at no net cost to public purse in 2015. Pharm J 2016;297(7893) online. doi: 10.1211/PJ.2016.20201678

[79] Watson MC, Holland R, Ferguson J et al. Community Pharmacy Management of Minor Illness: the MINA Study. Final report to Pharmacy Research UK. 2014. Available at: https://pharmacyresearchuk.org/wp-content/uploads/2014/01/MINA-Study-Final-Report.pdf (accessed April 2018)

[80] Royal Pharmaceutical Society. Shaping pharmacy for the future - improving urgent and emergency care through better use of pharmacists. 2014. Available at: https://www.rpharms.com/Portals/0/RPS\%20document\%20library/Open\%20access/Policy\%20state ments/urgent-and-emergency-care.pdf (accessed April 2018)

[81] Wright D, Twigg M \& Thornley T. Chronic obstructive pulmonary disease case finding by community pharmacists: a potential cost-effective public health intervention. Int J Pharm Pract 2015;23(1):83-85. doi: 10.1111/ijpp.12161 
[82] Wright $D$, Twigg $M$, Barton $G$ et al. An evaluation of a multi-site community pharmacy-based chronic obstructive pulmonary disease support service. Int J Pharm Pract 2015;23(1):36-43. doi: 10.1111/ijpp.12165

[83] Thavorn K \& Chaiyakunapruk N. A cost-effectiveness analysis of a community pharmacist-based smoking cessation programme in Thailand. Tob Control 2008;17(3):177-182. doi: $10.1136 /$ tc. 2007.022368

[84] Perraudin C, Le Vaillant M \& Pelletier-Fleury N. Cost-effectiveness of a community pharmacist-led sleep apnea screening program - a Markov model. PLoS ONE 2013;8(6):e63894. doi: 10.1371/journal.pone.0063894

[85] Lowres N, Freedman SB, Redfern J et al. Screening education and recognition in community pharmacies of atrial fibrillation to prevent stroke in an ambulant population aged $\geq 65$ years (SEARCHAF stroke prevention study): a cross-sectional study protocol. BMJ Open 2012;2(3). doi: 10.1136/bmjopen-2012-001355

[86] Agomo CO, Ogunleye J \& Portlock J. A survey to identify barriers in the public health role of community pharmacists. J Pharm Health Serv Res 2016;7(4):253-261. doi: 10.1111/jphs.12153

[87] Agomo CO \& Ogunleye J. An investigation of strategies enhancing the public health role of community pharmacists: a review of knowledge and information. J Pharm Health Serv Res 2014;5(2):135-145. doi: 10.1111/jphs.12056

[88] Bush J, Langley CA \& Wilson KA. The corporatization of community pharmacy: implications for service provision, the public health function, and pharmacy's claims to professional status in the United Kingdom. Res Soc Adm Pharm 2009;5(4):305-318. doi: 10.1016/j.sapharm.2009.01.003

[89] Saramunee K, Krska J, Mackridge A et al. How to enhance public health service utilization in community pharmacy? General public and health providers' perspectives. Res Soc Adm Pharm 2014;10(2):272-284. doi: 10.1016/j.sapharm.2012.05.006

[90] Agomo CO. Why UK pharmacy must adapt to the increasing demands of professionalism in practice. Int J Pharm Pract 2012;20(5):320-323. doi: 10.1111/j.2042-7174.2012.00200.x

[91] Agomo CO. Why improving the work-life balance of pharmacists might benefit employers and the profession. J Pharm Health Serv Res 2012;3(3):179-181. doi: 10.1111/j.1759-8893.2012.00096.x 
[92] The Scottish Government. Prescription for Excellence: a Vision and Action Plan for the Right Pharmaceutical Care through Integrated Partnerships and Innovation. 2013. Available at: http://www.gov.scot/resource/0043/00434053.pdf (accessed April 2018).

[93] Agomo C. Why partnerships may be a magic wand. 2012. Pharm J 2012;288. Available at: http://www.pharmaceutical-journal.com/opinion/comment/why-partnerships-may-be-a-magicwand/11092342.article (accessed April 2018)

[94] Agomo C, Ogunleye J \& Portlock J. A survey to identify strategies to enhance the public health role of community pharmacists. Available at: https://researchportal.port.ac.uk/portal/files/4980801/A_survey_to_identity_barriers.pdf (accessed April 2018)

[95] Agomo CO, Ogunleye J \& Portlock J. Strategies enhancing the public health role of community pharmacists: a qualitative study. J Pharm Health Serv Res 2016;7(2):97-104. doi: 10.1111/jphs.12131 [96] International Pharmaceutical Federation. Transforming our workforce. 2016. Available at: https://www.fip.org/files/fip/PharmacyEducation/2016_report/FIPEd_Transform_2016_online_versi on.pdf (accessed April 2018)

[97] International Pharmaceutical Federation. Pharmaceutical Workforce Development Goals. 2016. Available at: https://fip.org/files/fip/PharmacyEducation/2016_report/2016-11-Educationworkforce-development-goals.pdf (accessed April 2018)

[98] International Pharmaceutical Federation. 2012 FIP Global Pharmacy Workforce Report. 2012. Available at: https://www.fip.org/files/members/library/FIP_workforce_Report_2012.pdf (accessed April 2018)

[99] DiPietro Mager NA \& Farris KB. The Importance of Public Health in Pharmacy Education and Practice. Am J Pharm Educ 2016;80(2). doi: 10.5688/ajpe80218

[100] Agomo C. Strategies enhancing the public health role of community pharmacists in the UK [DProf thesis]. Hendon, London: Middlesex University, UK; 2017

[101] International Pharmaceutical Federation. Quality Assurance of Pharmacy Education: the FIP Global Framework. $2014 . \quad$ Available at: 
http://www.fip.org/files/fip/PharmacyEducation/Quality_Assurance/QA_Framework_2nd_Edition_o nline_version.pdf (accessed April 2018)

[102] Pharmaceutical Services Negotiating Committee. PSNC briefing 052/16: flu vaccination: the benefits of a community pharmacy service 2016. Available at: http://psnc.org.uk/wpcontent/uploads/2013/04/PSNC-Briefing-052.16-Flu-vaccination-The-benefits-of-a-communitypharmacy-service.pdf (accessed April 2018)

[103] Truong H \& Patterson BY. Professional and educational initiatives, supports, and opportunities for advanced training in public health. Am J Pharm Educ 2010;74(7):122. doi: 10.5688/aj7407122 